\title{
Exploration and identification of Anredera cordifolia morphological characters in the highlands and lowlands
}

\author{
YAYA HASANAH ${ }^{\vee}$, LISA MAWARNI \\ Agrotechnology Program, Faculty of Agriculture, Universitas Sumatera Utara. Jl. Prof. A. Sofyan No. 3, Kampus USU Padang Bulan, Medan 20155 , \\ North Sumatra, Indonesia. Tel.: +62-61-8213236, Fax.: +62-61-8211924, •email: yaya@usu.ac.id
}

Manuscript received: 2 April 2020. Revision accepted: 25 May 2020.

\begin{abstract}
Hasanah Y, Mawarni L. 2020. Exploration and identification of Anredera cordifolia morphological characters in the highlands and lowlands. Biodiversitas 21: 2759-2766. Information about genetic diversity and relationships between accessions is very important in plant breeding programs, because with the availability of this information, it is easier to determine relationship between accessions that can be used as a basis for plant selection. The objective of the research was to evaluate the morphological characteristics and relationship of binahong or Anredera cordifolia (Ten.) Steenis) accessions in the lowlands and highlands. The study was conducted in Karo (highlands) and Medan (lowlands), North Sumatra, Indonesia, from May to August 2019. This research used a descriptive method. Before the survey and exploration are conducted, first a pre-survey was conducted by gathering information from key informants and other informants. The characteristic of morphological diversity A. cordifolia can be distinguished based on leaf color, stem shape, axillary tuber, rhizome, and the presence of flowers. The dendrogram relationship between accessions is based on a genetic similarity matrix using cluster analysis. Analysis of qualitative morphological characters revealed the existence of variability among $A$. cordifolia accessions. There is a far relationship relation between A. cordifolia plants in Karo and Medan with Eucludian range of 0.446 to 57.725, hence resulting in two clusters that show differences in the variation of A. cordifolia plants. There is a distant relationship relation with M4 and M7 accessions with a dissimilar distance of 57,725 and the closest relationship with accession K1 and K2 with a dissimilar distance of 0.446 . Therefore, morphological characterization in the research is valuable to understand the variability of genetic of A. cordifolia accessions in the lowland and highland in North Sumatra.
\end{abstract}

Keywords: Anredera cordifolia, binahong, dendrogram, morphology, relationship

\section{INTRODUCTION}

At present, the utilization of medicinal plants in the country tends to increase along with public awareness to consume natural medicines. Medicinal plants have long been used as alternatives for the prevention and treatment of various diseases. Binahong (Anredera cordifolia (Ten.) Steenis) is one of the medicinal plants and is popular among the people in Indonesia. It is known in many countries as ornamental plant, but in Australia, South Africa, New Zealand has become an invasive species (Weber 2017). This species reproduces vegetatively, has leaf axillary tubers which play an important role in spreading species quickly (Stancic and Mihelj 2010; Kottaimuthu et al. 2011). The appearance and actual status of this species in Algeria reported by Sakhraoui et al. (2019), it is the only species that represents the Basellaceae family in Algeria.

Use of natural ingredients, either as medicine or other purposes tend to be increased, especially with the issue of back to nature as well as a prolonged crisis which resulting in decreased purchasing power against modern medicine. Traditional medicine (herbal medicine) is widely used by the middle class down especially in prevention disease preventive), healing (curative), health recovery (rehabilitative) as well as health promotion (promotive). (Syamsiah 2014).
Anredera cordifolia as a medicinal plant has many functions including anti-hyperlipidemic (Lestari et al. 2015; Sukandar et al. 2014), anti-bacterial (Amertha et al. 2012; Darsana et al. 2012; Kartika et al. 2016; Angga et al. 2016; Maharani et al. 2018; Pitaloka et al. 2018), antihypertension (Garmana et al. 2016), antioxidant (Djamil et al. 2012), anti-diabetes (Sukandar et al. 2016), analgesic effect (Kurniawan et al. 2014), and wound healing (Kaur et al. 2014; Sukrama et al. 2017), anti-obesity (Sukandar et al. 2016). A. cordifolia chemical contents are flavonoids, alkaloids, saponins, triterpenoids, quoin, sesquiterpenoids and monoterpenes. A. cordifolia rhizomes contain flavonoids, polyphenols, tannins, and steroids (Murni et al. 2011; Garmana et al. 2014; Souza et al. 2014).

Optimal growth and productivity of A. cordifolia is determined by the type of plant and the content of secondary metabolites in A. cordifolia. The small genetic diversity in $A$. cordifolia causes difficulties in obtaining good quality A. cordifolia. Therefore, efforts are needed to increase the genetic variation of $A$. cordifolia plants. One effort that can be done is by exploring $A$. cordifolia germplasm. A. cordifolia germplasm is collected, then characterized to identify the characteristics and potential of germplasm.

Anredera cordifolia can grow in the lowlands and highlands. Differences in growth location cause differences in growth and development of A. cordifolia due to differences in microclimate. Therefore, this research 
activity was carried out by exploration of $A$. cordifolia in the highlands (Karo) and lowlands (Medan) of North Sumatra, Indonesia.

Anredera cordifolia's research to date has largely examined the role of $A$. cordifolia and its properties as a medicinal plant (Astuti et al. 2011; Sakti et al. 2019; Maharani et al. 2018; Sugiyarto et al. 2014; Dwitiyanti et al. 2019; Susanti 2019; Nazliniwaty et al. 2019; Leliqia et al. 2017), aquaculture research, chicken research and the growth and physiological character of A. cordifolia (Sukandar et al. 2014; Lubis et al. 2018; Syahputra et al. 2018; Widodo et al. 2018; Hasanah et al. 2019; Tampubolon et al. 2019; Hasibuan et al. 2020; Hasanah et al. 2020; Manurung et al. 2020), morphological study of $A$. cordifolia (Mahyuni et al. 2015); A. cordifolia as botanical pesticide on paddy (Yulia and Widiantini 2018); etnobotanical study of A. cordifolia (Mesfin et al. 2013; Nahdi et al. 2016); molecular marker of A. cordifolia (Royani et al. 2018); morphology and isozyme variation of A. cordifolia accessions from southeastern part of Central Java (Restikania et al. 2019)

Studies on the genetic diversity and identification of $A$. cordifolia accessions in the highlands and lowlands in North Sumatra have not been reported. Exploratory research is preliminary research, which forms the basis of more conclusive research in collecting data to obtain $A$. cordifolia morphological performance from various accessions. Exploration activities are tracking or exploring, searching, collecting, and researching germplasm types. The initial approach in this activity is to inventory plants and followed by characterization of morphological and agronomic characters. Therefore, this study aims to evaluate the morphological characteristics and relationship of $A$. cordifolia accessions in the lowlands and highlands.

\section{MATERIALS AND METHODS}

The research was conducted by survey method for exploration of $A$. cordifolia accessions in Karo (i.e. Simpang Empat, Berastagi, Barus Jahe) and Medan (i.e. Medan Marelan, Medan Helvetia, Medan Selayang, Medan Johor) of North Sumatra, Indonesia (Figure 1). The research was conducted in May-August 2019. A total of 13 A. cordifolia accessions from lowlands and highlands were used to observe morphological characters. These accessions were collected from various places in the form of living plant collections.

The materials used were $A$. cordifolia accessions found in Karo and Medan. The tools used were GPS, plastic ropes, cameras, A. cordifolia plant descriptor guides, stationery, calipers, hand sprayers, rulers, paper.

This research used descriptive methods in the form of direct observation techniques on objects observed in the field. Before the survey and exploration are conducted, first a pre-survey was conducted by gathering information from key informants and other informants. Key informants are community leaders, while other informants are determined based on information from key informants using the snowball sampling method.

The data source used was obtained by observing qualitative morphological characters at the location including the character of leaf (shape, color, venation), stem (shape, color), axillary tubers (shape, color), rhizome (shape, color) and flower (presence, color) using the International Plant Genetic Resources Institute (IPGRI) descriptor. Five samples were taken from each observation location. Observation of supporting data includes the condition of the environment around the plant (altitude, GPS, temperature, soil $\mathrm{pH}$, light intensity, rainfall), presented in Table 1.

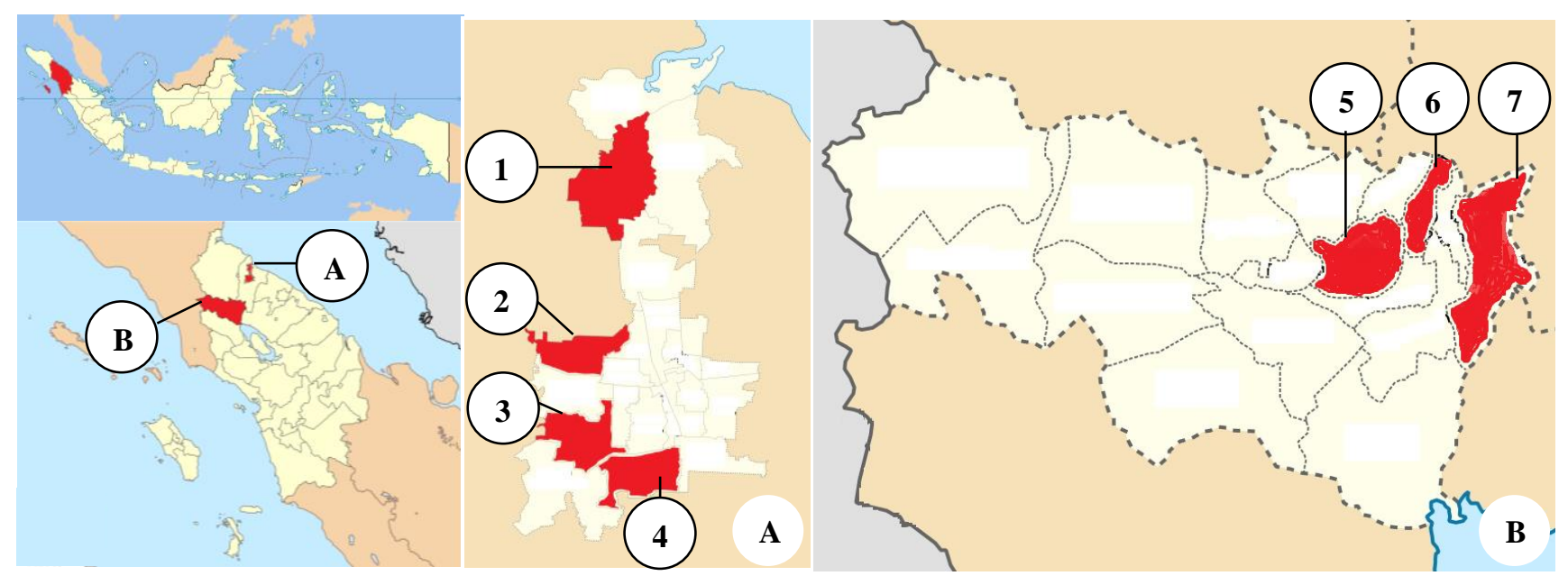

Figure 1. Schematic map research site in Medan (A) and Karo (B), North Sumatra, Indonesia as a sampling site (O): 1. Medan Marelan, 2. Medan Helvetia, 3. Medan Selayang, 4. Medan Johor, 5. Simpang Empat, 6. Berastagi, 7. Barus Jahe 


\section{RESULTS AND DISCUSSION}

\section{Anredera cordifolia morphological characters}

Based on A. cordifolia exploration in Karo (highlands), six locations were found consisting of four locations in Barus Jahe, one location in Berastagi, and one location in Simpang Empat. Exploration results in Medan (lowland) found seven locations, namely one location in Medan Helvetia, one location in Medan Johor, two locations in Medan Marelan, and three locations on Medan Selayang.

Based on observations of $A$. cordifolia found in Karo, it was found that two A. cordifolia locations in Barus Jahe are wild plants (not cultivated), while two locations in Barus Jahe, one location in Berastagi and one location in Simpang Empat are cultivated plants. Meanwhile, A. cordifolia found in Medan has been cultivated by the community.

Environmental data around A. cordifolia plants in Karo and Medan are presented in Table 1. Based on these data, it can be seen that $A$. cordifolia can grow well in the lowlands (<700 $\mathrm{m}$ a.s.1) and highlands (> $700 \mathrm{~m}$ a.s.l) with a temperature range of $15-34^{\circ} \mathrm{C}$, with range soil $\mathrm{pH}$ 5.0-6.5, the average of rainfall $173-274 \mathrm{~mm} /$ month, light intensity 211-1338 lux. In general, the A. cordifolia plants were found in the shade and were not directly exposed to solar radiation, except the accession Medan 1.

Based on Table 2, it can be seen that the accessions of A. cordifolia in the lowlands and highlands have similarities in the shape, color, and venation of leaves, the shape and color of the stems, axillary tubers, rhizomes, and flowers. Variations in the shape of the leaves are the heart, rounded heart, and elongated heart. A. cordifolia leaf color found in green, dark green, and green varies, with pin venation of leaves and separated pin venation of leaves. Woody stems with reddish-green, brownish-red, and red stems color. Axillary tubers are irregularly shaped with green, brown, and brownish-green. Irregular rhizome shape with a greenish and brownish color.

All A. cordifolia accessions from Karo have no flower. Meanwhile, accessions from Medan, only two accessions that have white/cream flowers. This proved that the weather conditions in the highlands are not suitable for the initiation of $A$. cordifolia flowering. In the lowlands generally A. cordifolia will flower after being planted for 2 months, whereas in the highlands it does not have flower. This is presumable because the lowest temperature in Karo $\left(15-16{ }^{\circ} \mathrm{C}\right)$ resulted in the failure of flowering initiation. Wigge (2013); Heggi and Haliday (2005); Thines et al. (2014) stated that in many plant species, warm temperature is a strong signal for flowering, and flowering to this cue appears to act through multiple signaling pathways, including the components of the photoperiod pathway. In accordance with Thakur et al. (2010) that cold temperatures induce flower abortion, pollen, and ovular infertility.

\section{Cluster analysis}

Cluster analysis is an analysis to group similar elements as research objects to become distinct and mutually exclusive clusters. The purpose of cluster analysis is to group objects based on the similarity of characteristics between the objects (Suratman et al. 2015). These objects will be classified into one or more clusters (groups) so that objects that are in one cluster will be similar to one another (Santoso 2014).

The phenotype relationship is a relationship based on the analysis of several phenotypic performances of an organism (Rahaman et al. 2019). The relationship between two individuals or two populations can be measured based on the similarity in the number of characters with the assumption that the different characters are caused by genetic makeup.

Based on the results of cluster analysis, it is obtained the proximity matrix data (Table 3 ), it is known that the euclidian distance of 13 A. cordifolia accessions in Karo and Medan is in the range of $0.446-57.725$. The range proved that the coefficient of dissimilarity in the population of $A$. cordifolia accessions at all locations is broad. The great dissimilarity suggests that the variation found in the population is broad. The same thing was also found in the research of Yusran and Maemunah (2010) on the glutinous corn plant, obtained dendrogram results which showed the greater the distance formed from grouping, the smaller the diversity formed.

Based on the dendrogram (Figure 2), it can be seen that the accessions of $A$. cordifolia can be grouped into 2 clusters on a distance scale of 25, that the accessions of $A$. cordifolia in Karo (K1-K6) and Medan accessions (M1, M2, M3, M4, and M5) are all in one cluster. While cluster 2 only has one member (M7). The M7 accession was obtained from Jl. Ampera Setiabudi, Medan, where the $A$. cordifolia plant has a phenotypic different from the others because the M7 accession has brownish-colored tubers, the color of the stem is purplish-green, but some other characters are still similar.

Analysis of relationship relation based on the morphological character of $A$. cordifolia accessions on a distance scale of 23 showed the formation of 3 groups of plant relationships. The first group consists of $\mathrm{K} 1, \mathrm{~K} 2, \mathrm{~K} 3$, K4, K5, K6, M1, M4, M5, M6, the second group consists of M2 and the third group consists of M7. The grouping dendrogram analysis is based on the number of qualitative morphological characters in common. Although the $A$. cordifolia is in the same area if the environment where it grows is different it will affect the growth and development of plants expressed through the appearance of the phenotype. This is in accordance with Irawan and Purbayanti (2008) that although a cultivar originates from the same area, if the environment where it grows is different it will affect genetic diversity and also genotype originating from the same region does not always belong to the same group. The more characteristics in common, the closer the relationship.

Exploration for genetic improvement of each species originates from genetic variation that plays an important role in the Plant Improvement program (Johnson et al. 2010). In germplasm characterization in Indonesia, morphological markers have been commonly used to evaluate genetic variation between and within species, cultivars, or populations accession (Acquaah 2012; Padmini et al. 2013). 
Table 1. Data supporting the environment around Anredera cordifolia accessions in Karo and Medan, North Sumatra, Indonesia

\begin{tabular}{|c|c|c|c|c|c|c|c|}
\hline $\begin{array}{c}\text { Accession } \\
\text { name }\end{array}$ & Collection site & GPS & $\begin{array}{l}\text { Altitude } \\
\text { (m a.s.l) }\end{array}$ & $\begin{array}{c}\text { Air temp. range } \\
\left({ }^{\circ} \mathrm{C}\right)\end{array}$ & $\begin{array}{l}\text { Light intensity } \\
\text { (lux) }\end{array}$ & $\begin{array}{l}\text { Soil } \\
\text { pH }\end{array}$ & $\begin{array}{l}\text { Average rainfall } \\
\text { (mm/month) }\end{array}$ \\
\hline Karo 1 & Barus Jahe, Jl. Gotong Royong & $\mathrm{N}: 03^{0} 07.035^{\prime} \mathrm{E}: 098^{0} 34.736^{\prime}$ & 1252 & $16-32$ & 832 & 6.0 & 246 \\
\hline Karo 2 & Barus Jahe & N: $03^{0} 06.900^{\prime} E: 098^{0} 34.835^{\prime}$ & 1253 & $16-32$ & 827 & 6.0 & 246 \\
\hline Karo 3 & Barus Jahe & $\mathrm{N}: 3^{0} 06.53^{\prime} \mathrm{E}: 098^{0} 34.50^{\prime}$ & 1252 & $16-32$ & 285 & 6.0 & 246 \\
\hline Karo 4 & Barus jahe & 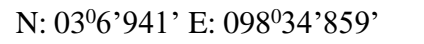 & 1256 & $16-32$ & 355 & 6.5 & 246 \\
\hline Karo 5 & Berastagi, Jl. Mesjid No.12 & $\mathrm{N}: 3^{\circ} .19^{\prime} 5578, \mathrm{E}: 98^{\circ} .50^{\prime} 17^{\prime \prime}$ & 1400 & $15-30$ & 792 & 6.5 & 246 \\
\hline Karo 6 & Simpang Empat, Desa Gajah & $\mathrm{N}: 3^{\circ} 175859^{\prime} \mathrm{E}: 9^{\circ} 465104^{\prime}$ & 1332 & $15-30$ & 316 & 6.5 & 173 \\
\hline Medan 1 & Medan Selayang, Jl. Dr. Mansyur No. 41 A & $\mathrm{N}: 03^{0} 34.055 \mathrm{E}: 098^{0} .39 .038^{\prime}$ & 26 & $25-34$ & 1338 & 5.0 & 274 \\
\hline Medan 2 & Medan Johor, Jl. Aswad No.7 & N: 03031.139' E: 098 ${ }^{0} .40 .018^{\prime}$ & 25 & $25-34$ & 568 & 6.5 & 274 \\
\hline Medan 3 & Medan Helvetia, Jl. Persatuan No. 4 & N: 03036.692' E: 098 ${ }^{0} .39 .497^{\prime}$ & 24 & $24-33$ & 312 & 6.0 & 175 \\
\hline Medan 4 & Medan Marelan, Jl. Marelan VII Pasar 1 Tengah & $\mathrm{N}: 03^{0} 41.545^{\prime} \mathrm{E}: 098^{0} .38 .423^{\prime}$ & 6 & $24-33$ & 792 & 6.0 & 175 \\
\hline Medan 5 & Medan Marelan, Jl. Marelan VII & $\mathrm{N}: 03^{0} 41.525^{\prime} \mathrm{E}: 098^{0} .38 .858^{\prime}$ & 8 & $24-33$ & 736 & 6.5 & 175 \\
\hline Medan 6 & Medan Selayang, Jl. Ampera Timur Setia Budi No. 536 & $\mathrm{~N}: 03^{0} 34.529^{\prime} \mathrm{E}: 098^{0} .38 .215^{\prime}$ & 28 & $24-33$ & 211 & 5.0 & 274 \\
\hline Medan 7 & Medan Selayang, Jl. Ampera Setia Budi No. 249 & N: 03ㅜㄴ.495' E: $098^{0} .38 .192^{\prime \prime}$ & 34 & $25-34$ & 231 & 6.0 & 274 \\
\hline
\end{tabular}

Table 2. Anredera cordifolia morphological characters in Karo and Medan, North Sumatra, Indonesia

\begin{tabular}{|c|c|c|c|c|c|c|c|c|c|c|c|}
\hline \multirow{2}{*}{$\begin{array}{c}\text { Accession } \\
\text { name }\end{array}$} & \multicolumn{3}{|c|}{ Leaf } & \multicolumn{2}{|c|}{ Stem } & \multicolumn{2}{|c|}{ Axillary tubers } & \multicolumn{2}{|c|}{ Rhizome } & \multicolumn{2}{|c|}{ Flower } \\
\hline & Shape & Color & Venation & Shape & Color & Shape & Color & Shape & Color & Presence & Color \\
\hline Karo 1 & Heart leaf & Green & Pinnate & Woody & Reddish green & Irregular & Green & Irregular & Brownish & Absent & - \\
\hline Karo 2 & Heart leaf & Green & Pinnate & Woody & Purplish green & Irregular & Green & Irregular & Brownish & Absent & - \\
\hline Karo 3 & Heart leaf & Green & Pinnate & Woody & Purplish green & Irregular & Green & Irregular & Brownish & Absent & - \\
\hline Karo 4 & Heart leaf & Green & Pinnate & Woody & Brownish green & Irregular & Green & Irregular & Brownish & Absent & - \\
\hline Karo 5 & Elongated heart leaf & Green & Pinnate & Woody & Reddish green & Irregular & Brownish & Irregular & Greenish & Absent & - \\
\hline Karo 6 & Elongated heart leaf & Green & Pinnate & Woody & Reddish green & Irregular & Green & Irregular & Greenish & Absent & - \\
\hline Medan 1 & Heart leaf & Dark green & $\begin{array}{l}\text { Pinnate does not meet, } \\
\text { red leaf reinforcement }\end{array}$ & $\begin{array}{l}\text { Woody/ } \\
\text { herbaceous }\end{array}$ & Red & Irregular & Brownish & Irregular & Brownish & Absent & - \\
\hline Medan 2 & Rounded heart leaf & Green & Pinnate does not meet & Woody & Reddish-brown & Irregular & Brownish & Irregular & Brownish & Present & Cream \\
\hline Medan 3 & Heart leaf & Green & Pinnate & Woody round & Reddish green & Irregular & Green & No & No & Absent & - \\
\hline Medan 4 & Heart leaf & Dark green & Costa & Woody round & Green & Irregular & Green & No & No & Absent & - \\
\hline Medan 5 & Heart leaf & Green varies & Pinnate & Woody & Reddish & Irregular & Green & No & No & Present & White \\
\hline Medan 6 & Heart leaf, flat periphery & Green varies & Pinnate & Woody & Brownish green & Irregular & Brownish green & No & No & Absent & - \\
\hline Medan 7 & Heart leaf, uneven edges & Green & Pinnate & Woody & Purplish green & Irregular & Brownish & No & No & Absent & - \\
\hline
\end{tabular}


Tabel 3. Proximity matrix of Anredera cordifolia accessions

\begin{tabular}{|c|c|c|c|c|c|c|c|c|c|c|c|c|c|}
\hline \multirow{2}{*}{ Case } & \multicolumn{13}{|c|}{ Squared Euclidean Distance } \\
\hline & K1 & $\mathbf{K 2}$ & K3 & K4 & K5 & K6 & M1 & M2 & M3 & M4 & M5 & M6 & M7 \\
\hline$\overline{\mathrm{K} 1}$ & 0.000 & 0.446 & 16.054 & 12.191 & 11.601 & 15.187 & 29.643 & 29.832 & 12.068 & 31.277 & 27.117 & 17.069 & 39.550 \\
\hline $\mathrm{K} 2$ & 0.446 & 0.000 & 15.608 & 10.854 & 12.046 & 15.633 & 27.414 & 26.712 & 12.514 & 32.614 & 28.454 & 15.732 & 39.104 \\
\hline K3 & 16.054 & 15.608 & 0.000 & 5.646 & 16.855 & 10.425 & 11.806 & 29.220 & 7.305 & 27.406 & 23.246 & 10.523 & 33.895 \\
\hline K4 & 12.191 & 10.854 & 5.646 & 0.000 & 12.992 & 6.562 & 15.668 & 32.192 & 3.442 & 24.434 & 20.275 & 4.877 & 29.141 \\
\hline K5 & 11.601 & 12.046 & 16.855 & 12.992 & 0.000 & 10.473 & 34.486 & 41.852 & 12.869 & 36.121 & 27.918 & 15.174 & 34.959 \\
\hline K6 & 15.187 & 15.633 & 10.425 & 6.562 & 10.473 & 0.000 & 21.992 & 53.226 & 6.439 & 23.626 & 21.488 & 12.787 & 36.616 \\
\hline M1 & 29.643 & 27.414 & 11.806 & 15.668 & 34.486 & 21.992 & 0.000 & 39.721 & 14.255 & 22.731 & 37.584 & 28.172 & 49.744 \\
\hline M2 & 29.832 & 26.712 & 29.220 & 32.192 & 41.852 & 53.226 & 39.721 & 0.000 & 39.200 & 45.218 & 37.015 & 34.374 & 57.725 \\
\hline M3 & 12.068 & 12.514 & 7.305 & 3.442 & 12.869 & 6.439 & 14.255 & 39.200 & 0.000 & 15.890 & 15.049 & 8.320 & 30.801 \\
\hline M4 & 31.277 & 32.614 & 27.406 & 24.434 & 36.121 & 23.626 & 22.731 & 45.218 & 15.890 & 0.000 & 14.852 & 36.938 & 54.944 \\
\hline M5 & 27.117 & 28.454 & 23.246 & 20.275 & 27.918 & 21.488 & 37.584 & 37.015 & 15.049 & 14.852 & 0.000 & 16.745 & 46.741 \\
\hline M6 & 17.069 & 15.732 & 10.523 & 4.877 & 15.174 & 12.787 & 28.172 & 34.374 & 8.320 & 36.938 & 16.745 & 0.000 & 31.323 \\
\hline M7 & 39.550 & 39.104 & 33.895 & 29.141 & 34.959 & 36.616 & 49.744 & 57.725 & 30.801 & 54.944 & 46.741 & 31.323 & 0.000 \\
\hline
\end{tabular}

Note : This is a dissimilarity matrix. K1: Karo 1, K2: Karo 2, K3: Karo 3, K4: Karo 4, K5: Karo 5, K6: Karo 6, M1: Medan 1, M2: Medan 2, M3: Medan 3, M4: Medan 4, M5: Medan 5, M6: Medan 6, M7: Medan 7

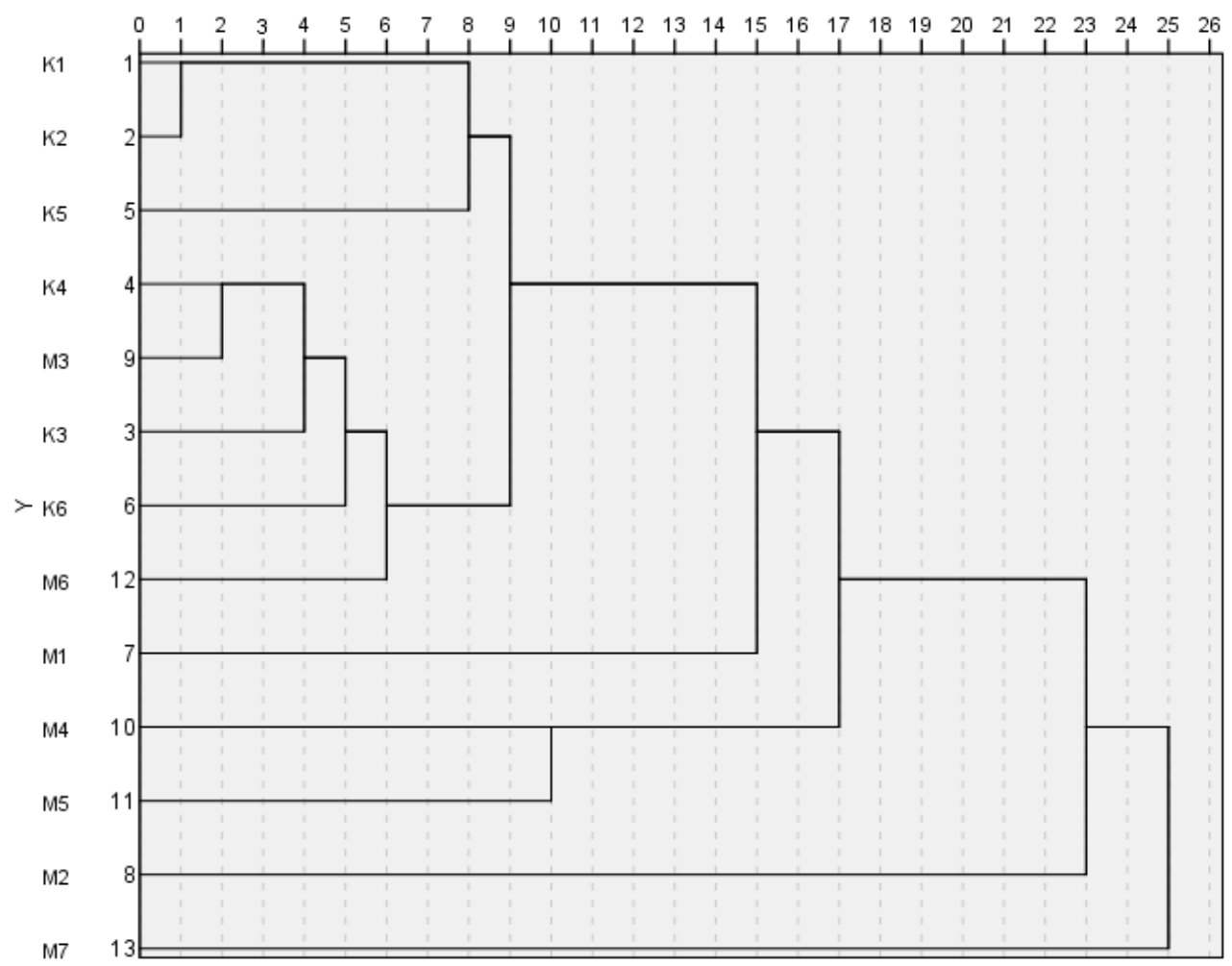

Figure 2. Dendrogram Anredera cordifolia grouping in Karo and Medan, North Sumatra, Indonesia

Analysis of relationship relation based on the morphological character of A. cordifolia accessions on a distance scale of 17 showed the formation of 4 groups of plant relationships. The first group consists of $\mathrm{K} 1, \mathrm{~K} 2, \mathrm{~K} 3$, $\mathrm{K} 4$, K5, K6, M1, M3, M6, the second group consists of M2, the third group consists of M4 and M5, the fourth group consists of M7. The separation of these four groups occurred because of differences in leaf color, stem shape, tuber shape, and the presence of flowers. Planting locations, in which group 1 is $A$. cordifolia accessions in the highlands namely Karo and Medan Regency, are united by the same 2 characters while the second group is $A$. cordifolia cultivated in the lowlands namely Medan. This proves that not always the adjacent geographical location is related to the same cluster diversity. Therefore, it is suspected that genetic diversity and geographic distribution have no correlation in this study. The A. cordifolia accession grouping does not always show similarities based on geographical origin, but may be due to genetic similarities. Genetic diversity in A. cordifolia is thought to be a result of abiotic and biotic factors, therefore information and A. cordifolia collections from various locations are germplasm collections that are very important for plant breeding (Tang et al. 2014; Restikania et al. 2019). 


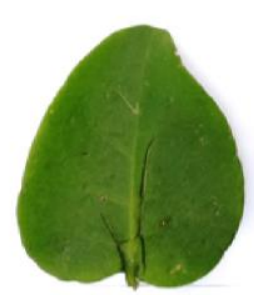

Heart leaf

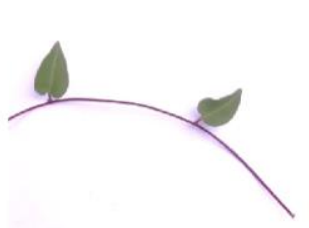

Stem reddish brown

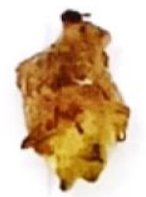

Axillary tuber brown

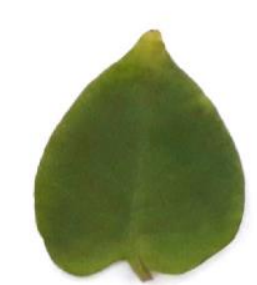

heart leaf, flat periphery

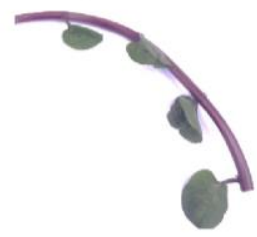

Stem red

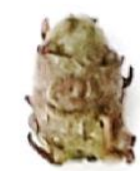

Axillary tuber brownish green



Heart leaf, uneven edges

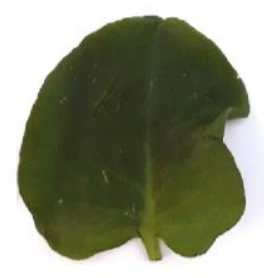

rounded heart leaf

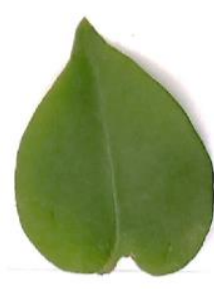

elongated heart leaf

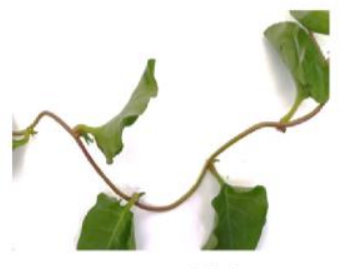

Stem reddish green
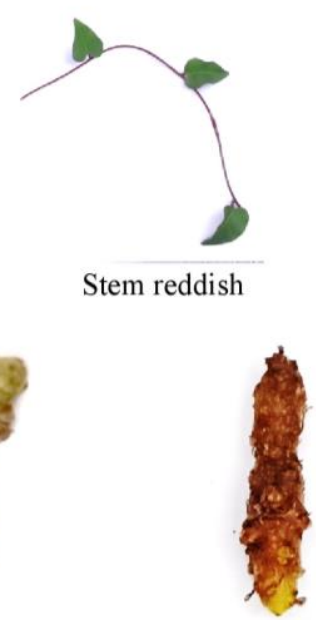

Axillary tuber green

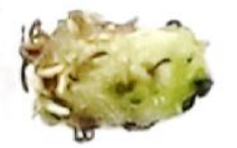

een
Rhizome-brownish

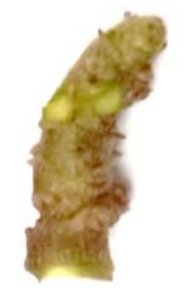

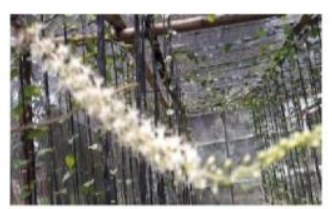

Rhizome- greenish

flower-white

Figure 3. The phenotypic appearance differences in 13 accessions of Anredera cordifolia in Karo and Medan, North Sumatra, Indonesia

Previous studies (Royani et al. 2018) on the performance of $18 \mathrm{~A}$. cordifolia accessions from various regions in Indonesia using ISSR molecular markers, showed that the dendrogram of 18 genetic accessions ranges from 0.39 to 1.00 . There are two major groups obtained from 18 A. cordifolia accessions, the first group consisting of 17 accessions and the second group only Tanjung Bungkak accession (Denpasar, Bali).

Figure 3 showed the phenotypic appearance differences of leaf color, stem color, axillary tuber color, rhizome color, and flower color. The morphological characters had different types of each parameter observation.

It has been concluded there is a far relationship relation between $A$. cordifolia plants in Karo and Medan with eucludian range of 0.446 to 57.725 , hence it produces two clusters that show differences in the variation of $A$. cordifolia plants. There is a distant relationship with M4 and M7 accessions with dissimilar distance of 57,725 and the closest relationship with accession $\mathrm{K} 1$ and $\mathrm{K} 2$ with dissimilar distance of 0.446 .

\section{ACKNOWLEDGEMENTS}

The authors gratefully thank the Directorate of Research and Community Service, Directorate General of Research Strengthening and Development, Ministry of Research, Technology and Higher Education for funding this research, in accordance with Research Assignment Agreement, Fiscal Year 2019 Number: 11/E1/KP.PTNBH/2019, dated March 29, 2019.

\section{REFERENCES}

Amertha IBPM, Soeliongan S, Kountul C. 2012. In vitro inhibition zone test of binahong (Anredera cordifolia) toward Staphylococcus aureus, Enterococcus faecalis, Escherichia coli, and Pseudomonas aeruginosa. Indon J Biomed Sci 6: 30-34.

Angga GR, Kartika S, Andayani, Soelistyowati. 2016. Potensi ekstrak daun Binahong (Anredera cordifolia) sebagai penghambat bakteri Vibrio harveyi. J Mar Aquat Sci 2 (2): 49-53. DOI: 10.24843/jmas.2016.v2.i02.49-53. [Indonesian]

Acquaah G. 2012. Principles of Plant Genetics and Breeding. 2nd ed. John Wiley \& Sons Ltd, UK. 
Astuti SM, Sakinah R, Andayani BM, Risch A. 2011. Determination of saponin compound from Anredera cordifolia (Ten) Steenis plant (binahong) to potential treatment for several diseases. J Agric Sci 3 (4): 224-232. DOI: $10.5539 /$ jas.v3n4p224

Darsana IGO, Besung INK, Mahatmi H. 2012. Potential of binahong (Anredera cordifolia (Ten.) Steenis) leaves in inhibiting the growth of Escherichia coli bacteria by in vitro. Indon Med Vet 1 (3): 337-351. [Indonesian]

Djamil R, Wahyudi PS, Wahono S, Hanafi M. 2012. Antioxidant activity of Anredera cordifolia (Ten.) Steenis. Intl Res J Pharm 3 (9): 241 243.

Dwitiyanti, Harahap Y, Elya B, Bahtiar A. 2019. Study of molecular docking of vitexin in binahong (Anredera cordifolia (Ten.) Steenis) leaves extract on Glibenclamide CYP3A4 interaction. Pharmacog J 11 (6): 1471-1476. DOI: 10.5530/PJ.2019.11.227

Garmana AN, Sukandar EY, Fidrianny I. 2016. Preliminary study of blood pressure-lowering effect of Anredera cordifolia (Ten.) Steenis) on Wistar rats. Intl J Pharmacog Phytochem Res 8 (2): 300-304.

Garmana AN, Sukandar EY, Fidrianny I. 2014. Activity of several plant extract against drug-sensitive and drug-resistant microbes. Procedia Chem 13: 164-169. DOI: 10.1016/j.proche.2014.12.021

Hasanah Y, Mawarni L, Rusmarilin H. 2019. Physiological characteristics of binahong (Anredera cordifolia (Ten.) Steenis) on application of natural plant growth regulator. Asian J Plant Sci 18 (3): 117-122. DOI: 10.3923 /ajps.2019.117.122

Hasanah Y, Mawarni L. 2020. The content of chlorophyll, stomatal density and cuticle thickness of binahong (Anredera cordifolia (Ten.) Steenis) accessions from Medan. IOP Conf Ser Earth Environ Sci 454: 012152. DOI: 10.1088/1755-1315/454/1/012152

Hasibuan AR, Mawarni L, Hasanah Y, Irsal, Fatiani. 2020. Application of bamboo shoot extract as natural plant growth regulator on the growth binahong (Anredera cordifolia (Ten.) Steenis.) in Karo. IOP Conf Ser Earth Environ Sci 454: 012170. DOI: 10.1088/17551315/454/1/012170

Heggie L, Halliday KJ. 2005. The highs and lows of plant life: temperature and light interactions in development. Intl J Dev Biol 49 (5-6): 675-687.

Irawan B, Purbayanti K. 2008. Karakterisasi dan kekerabatan kultivar padi lokal di desa Rancakalong, kecamatan Rancakalong, kabupaten Sumedang. Prosiding seminar nasional PTTI, 21-23 Oktober 2008 [Indonesian]

Johnson M, Nanthini AUR, Malar TRJJ. 2010. Isozyme variation and genetic relationships among three Plumbago species. J Ecobiotechnol 2 (5): 54-59.

Kartika GRA, Andayani S, Soelistyowati. 2016. Potential of binahong (Anredera cordifolia) leaf extract as an inhibitor of Vibrio harveyi bacteria. J Mar Aquat Sci 2: 49-53. [Indonesian]

Kaur G, Utami NV, Usman HA. 2014. Effect of topical application of binahong [Anredera cordifolia (Ten.) Steenis] leaf paste in wound healing process in mice. Althea Med J 1 (1): 6-11. DOI: 10.15850/amj.v1n1.289

Kottaimuthu R, Ganesan R, Vijayan R. 2011. Anredera cordifolia (Tenore) Steenis (Basellaceae) - A new record for India. Biol Divers 40: 5517- 5518 .

Kurniawan B, Carolia N, Pheilia A. 2014. The effectiveness of binahong leaf extract (Anredera cordifolia (Ten.) Steenis) and mefenamic acid as anti-inflammation to white male rats induced by karagenin. JUKE 4 (8): 151-157.

Leliqia NPE, Sukandar EY, Fidrianny I. 2017. Overview of efficacy, safety and phytochemical study of Anredera cordifolia (Ten.) Steenis. Pharmacol Online 1: 124-131.

Lestari D, Sukandar EY, Fidrianny I. 2015. Anredera cordifolia leaves extract as anti hyperlipidemia and endothelial fat content reducer in male Wistar rat. Intl J Pharm Clin Res 7 (6): 435-9.

Lubis TMA, Hasanah Y, Rahmawati N. 2018. The growth response of Madeira vine (Anredera cordifolia (Ten.) Steenis) on different levels of shade and application of fertilizer and biochar. JPT 5 (2): 183-191.

Maharani ES, Puspitawati R, Gunawan HA. 2018. Antibacterial effect of binahong (Anredera cordifolia (Ten.) Steenis) leaf infusion against black-pigmented bacteria. J Phys Conf Ser 1073: 032013. DOI: 10.1088/1742-6596/1073/3/032013

Mahyuni R, Girsang ESB, Hanafiah DS. 2015. Pengaruh pemberian kolkhisin terhadap morfologi dan jumlah kromosom tanaman binahong (Anredera cordifolia (Ten) Steenis). J Agroekotek 4 (1): 815-1821. [Indonesian]
Manurung GC T Manurung, Hasanah Y, Hanum C, Mawarni L. 2020. The role of bamboo shoot and shallot extracts combination as natural plant growth regulator on the growth of binahong (Anredera cordifolia (Ten.) Steenis.) in Medan. International Conference on Agriculture, Environment and Food Security (AEFS) 2019 IOP Conf. Series: Earth and Environmental Science 454 (2020) 012169 IOP Publishing. DOI: 10.1088/1755-1315/454/1/012169

Mesfin K, Tekle G, Tesfay T. 2013. Ethnobotanical study of traditional medicinal plants used by indigenous people of Gemand District Northern Ethiopia. J Med Plants Studies 1 (4): 32-37

Murni AS, Sakinah AMM, Andayani BMR, Awalludin R. 2011. Determination of saponin compound from Anredera cordifolia (Ten.) Steenis plant (binahong) to potential treatment for several diseases. J Agric Sci 3: 224-232.

Nahdi MS, Martiwi INA, Arsyah DC. 2016. The ethnobotany of medicinal plants in supporting the family health in Turgo, Yogyakarta, Indonesia. Biodiversitas 17 (2): 900-906. DOI: 10.13057/biodiv/d170268

Nazliniwaty, Suryanto, Damanik DD. 2018. The utilization of binahong (Anredera cordifolia (Ten.) Steenis) leaf as an anti-aging. Asian J Pharm Clin Res 11 (13): 87-89.

DOI: 10.22159/Ajpcr.2018.V11s1.26575.

Padmini SMPC, Pushpakumara DKNG, Samarasekera R. 2013. Morphological characterization of soursop (Annona muricata L.) germplasm in Sri Lanka. Trop Agricult Res 24 (4): 362-374.

Pitaloka DAE, Sukandar EY. 2018. Synergistic study on n-hexane extract of Anredera cordifolia (Ten.) Steenis leaves combined with antituberculosis drugs against drug-sensitive and drug-resistant of Mycobacterium tuberculosis. J App Pharm Sci 8 (05): 134-138.

Rahaman MM, Ahsan MM, Chen M. 2019. Data-mining Techniques for Image-based Plant Phenotypic Traits Identification and Classification. Scientific Reports Nature Research 9: 19526. DOI: 10.1038/s41598019-55609-6

Restikania, Suratman, Pitoyo A, Suranto. 2019. Morphology and isozyme variation among Madeira vine (Anredera cordifolia) accessions from southeastern part of Central Java, Indonesia. Biodiversitas 20 (10): 3024-3032. DOI: 10.13057/biodiv/d201035

Royani JI, Maulana NA, Dasumiati. 2018. Amplification of 5 accessions of DNA binahong (Anredera cordifolia (Ten.) Steenis) by inter simple sequence repeats as tool for molecular marker. IOP Conf Ser Earth Environ Sci 197: 012047. DOI: 10.1088/1755$1315 / 197 / 1 / 012047$

Sakhraoui N, Metallaoui S, Chefrour A. 2019. Naturalisation d'Anredera cordifolia (Basellaceae) en Algerie. Fl. Medit. 29: 159-162. Fl Medit 29: 159-162. DOI: 10.7320/FlMedit29.159

Sakti DS, Haresmita PP, Yuniarti N, Wahyuono S. 2019. Phagocytosis activity of binahong (Anredera cordifolia (Tenore.) Steenis) from Secang, Magelang, Central Java, Indonesia. J Farmasi Sains dan Komunitas (J Pharm Sci Community) 16 (1): 7-13.DOI: 10.24071/jpsc.001693. [Indonesian]

Santoso S. 2014. Statistik Multivariat Edisi Revisi Konsep dan Aplikasi dengan SPSS. (Multivariate Statistics Revised Edition Concept and Application with SPSS). Gramedia, Jakarta. [Indonesian]

Souza LF, de Barros IBI, Mancini E, de Martino L, Scandolera E, de Feo V. 2014. Chemical composition and biological activities of the essential oil from Anredera cordifolia grown in Brazil. Nat Prod Commun 9 (7): 1003-1006.

Stancic Z, Mihelj D. 2010. Anredera cordifolia (Ten.) Steenis (Basellaceae), naturalised in South Croatia. Nat Croat 19 (1): 273279.

Sugiyarto L, Kuswandi PC. 2014. Induksi kalus daun binahong (Anredera cordifolia L.) dalam upaya pengembangan tanaman obat tradisional. J Sains Dasar 3 (1): 56 - 60. DOI: DOI: 10.21831/jsd.v3i1.2787. [Indonesian]

Sukandar EY, Qowiyyah A, Larasari L. 2014 . Efek ekstrak metanol daun binahong (Anredera cordifolia (Ten.) Steenis) terhadap gula darah pada mencit model diabetes melitus. Jurnal Medika Planta 1 (4): 1-10.

Sukandar EY, Safitri D, Aini NN. 2016. The study of ethanolic extract of binahong leaves (Anredera cordifolia (Ten.) Steenis) and mulberry leaves (Morus nigra L.) in combination on hyperlipidemic induced rats. Asian J Pharm Clin Res 9 (6): 288-292.

Sukandar EY, Kurniati NF, Nurdianti AN. 2016. Antiobesity effect of ethanol extract of Anredera cordifolia (Ten.) Steenis leaves on obese male wistar rats induced by high carbohydrate diet. Intl J Pharm Pharm Sci 8 (4): 171-173. 
Sukrama DM, Wihandani DM, Manuaba AP. 2017. Topical binahong (Anredera cordifolia) leaf extract increases interleukin-6 and VEGF (vascular endothelial growth factor) during burn wound healing in Wistar rats infected with Pseudomonas aeruginosa. Biol Med (Aligarh) 9: 369. DOI: 10.4172/0974-8369.1000369.

Suratman, Pitoyo A, Mulyani S, Suranto. 2015. Assessment of genetic diversity among soursop (Annona muricata) populations from Java, Indonesia using RAPD markers. Biodiversitas 16 (2): 247-253.

Susanti H. 2019. Total phenolic content and antioxidant activities of binahong (Anredera cordifolia.). Jurnal Kedokteran dan Kesehatan Indonesia 10 (2): 171-175. DOI: 10.20885/JKKI.Vol10.Iss2.art9

Syahputra A, Hasanah Y, Barus A. 2018. Respons pertumbuhan binahong (Anredera cordifolia (Rens) Stennis) terhadap perbedaan bahan tanam dan komposisi media tanam. J Agroekotek 6 (1): 14-19. [Indonesian]

Syamsiah. 2014. Eksplorasi tumbuhan obat tradisional di Kecamatan Pamboang Kabupaten Majene Sulawesi Barat. J Bionature 15 (2): 127-136. [Indonesian]

Tampubolon JH, Hasanah Y, Ginting J. 2019. Respons pertumbuhan vegetatif binahong (Anredera cordifolia (Ten.) Steenis) terhadap aplikasi pupuk organik cair. J Pertanian Tropik 6 (1): 135-141. [Indonesian]

Tang XQ, Yan HH, Wang ZY, Li W, Wei YM, Ren CZ, Zha G, Peng YY. 2014. Evaluation of diversity and the relationship of Avena species based on agronomic characters. Intl J Agric Biol 16 (1): 14-22.
Thakur P, Kumara S, Malik JA, Berger JD, Nayyar H. 2010. Cold stress effects on reproductive development in grain crops: An overview. Environ Exp Bot 67 (3): 429-443.

Thines BC, Youn Y, Duarte MI, Harmon FG. 2014. The time of day effects of warm temperature on flowering time involve PIF4 and PIF5. J Exp Bot 65 (4): 1141-1151. DOI: 10.1093/jxb/ert487

Weber E. 2017. Invasive plant species of the world: A reference guide to environmental weeds. Boston.

Widodo N, Wihandoyo, Zuprizal, Dono ND. 2018. The effect of dietary binahong [Anredera cordifolia (Ten.) Steenis] leaf meal supplementation on total ileal bacteria and jejunal histomorphology in broiler chickens. Intl J Poult Sci 17 (10): 473-478. DOI: 10.3923/ijps.2018.473.478

Wigge PA. 2013. Ambient temperature signaling in plants. Curr Opin Plant Biol 16 (5): 661-666.

Yulia E, Widiantini F. 2018. Ekstrak tanaman binahong sebagai pengendali penyakit hawar pelepah daun padi binahong. J Fitopatol Indones 14 (4): 138-144. DOI: 10.14692/jfi.14.4.138. [Indonesian]

Yusran Y, Maemunah M. 2010. Karakterisasi morfologi varietas jagung ketan di kecamatan Ulu Bongka Kabupaten Tojo Una-una. Media Litbang Sulawesi Tengah 4 (1): 42-51. [Indonesian] 